\title{
大規模大深度地下工法の計画手法に関する研究
}

一標準モデル工事による地下工事計画手法の一考察一

\section{A STUDY OF HOW TO PLAN DEEP AND \\ WIDE EXCAVATION WORKS}

間 瀬 惇平*, 南林 和**, 寺林 肇***, 桂 - 純二****, 佐 藤 龍生***** Junpei MASE, Kazu NANBA YASHI, Hajime TERABA YASHI, Junji KATSURA and Tatsuo SATO

\begin{abstract}
This paper presents a study on construction planning approaches for building projects with deep and large-scale underground work. Based on a variety of data extracted from seventy recent underground construction examples in Japan, a shoring method for a virtual model project is specified. A comparison in construction schedule and cost of the model is made between the cases with ordinary/conventional concreting procedure combined H-sections strut ("Kumitate shuuchuu kiribari" Method) and with top down construction procedure ("Sakauchi" Method). Rough estimate diagrams derived from a technical calculation program for shoring method will assist easy and quick selection of the most optimum construction method.
\end{abstract}

Keywords :Excavation works, Retaining walls, Statistical Analysis, Standard Design Model, Retaining suport, Sakauchi Method

掘削工事、山留壁、統計分析、標準デザインモデル、山留支保工、逆打工法

1.はじめに

建築工事における地下工事は、コストや工程的に、その占めるウ ェートは大きい。特に、都市においては、地下の高利用や近隣環境 への影響などから、地下工事の適正な計画・実施の重要性は増大し ている。

筆者らは「建築工事における大規模・大深度掘削の設計と施工」1 に関しては長年の間、業務としてその適正化に努力して来ている。

山留工法の適・不適は安全性、経済性、工期などに大きな影響を 与える。216)

建築の適正工期は、建物の規模、地上階数、地下階数、構造種別、 建物用途、仕上げの種類よグレード、設備の程度、立地条件、気象 条件、労務資材の供給状況などにより変化する。

特に根切山留工事、基礎杭工事をともなう建物の新築工事の場合 は、地盤・地下水・地中障害物等と言った不特定・不明確な要因の もとに工事の計画・施工することになるので、工程計画上は不特定 なバラツキの多いものとなりやすい傾向になる。2)7

一般に発注者が工事請負契約を結ぶ場合には、建物全体工期のみ が設定され、請負者は指定された全体工期を制約条件として各部分
工事に当てられる工程を逆算し、その工程で可能な技術的検討を種 々行い、適切な工法選定を行い、場合によって設計変更をも加味し て、予定工期内に完成させている。 適性工期が新筑建物の企画設計段階で検討されれば、よりよい品質 の建物が、経済的なコストで、適切なる工期で発注が出来、請負側 もより少ないリスクで工事を推進することが出来る。

小規模工事の場合は、その工法の選定は割合に簡明であるが、大 規模大深度の地下工事をともなう場合は、その工法選定とその施工 計画の適正化のためには、充分なる調查研究が必要となる。

そこで本論文は、最近の大規模大深度の掘削工事を約70件の事例 の中からその平均的な標準モデル工事を想定し、その標準モデル工 事の技術計画・工程計画・コスト計画手法を明らかにして、安全性、 工程、コスト比較を解明し、企画計画段階におけるその地下工法計 画の適正化をはかるものである。

具体的には、順打工法(組立集中切梁)之逆打工法の比較を論じて、 企画計画段階における地下工法計画の適正化について考察を加え る。

\footnotetext{
* 大成建設侏建築本部建築部

** 大成建設(株経営本部情報企画部

*** 大成建設侏建築本部建築技術部

****大成建設(侏)東京支店

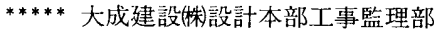

Building Construction Dept. Building Construction Div., Taisei Corporation Information Planning Dept. Business Planning and Administration Div., Taisei Corporation

Technology Promotion Dept. Building Construction Div., Taisei Corporation Tokyo Branch, Taisei Corporation

Quality Control Dept. Design \& Proposal Div., Taisei Corporation 


\section{2. 標準モデルエ事による地下エ法の計画}

2. 1 工法選定・概算ロジックの考え方

企画計画段階における、大規模大深度地下工法の計画手法につい て考える時、図 1 の如く、多種要因 (条件)，に対して各地下工法の 技術面・工程面・コス卜面において各々のその可能性を調查研究し 検討する必要がある。

\begin{tabular}{|c|c|c|c|c|}
\hline 棌価 & (1)技術面の㭘討 & 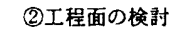 & (3)コスト面の検討 & 設計 \\
\hline \multirow{3}{*}{ 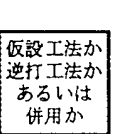 } & 5 & \& & 1 & \\
\hline & $\begin{array}{c}\text { (1)士留壁の推定 } \\
\text { (統計的手法) }\end{array}$ & \begin{tabular}{|c} 
(3)全体工期の推定 \\
(統計的手法)
\end{tabular} & $\begin{array}{l}\text { (4)全体二자の推定 } \\
\text { (统計的手法) }\end{array}$ & \multirow{4}{*}{$\begin{array}{l}\text { 設 } \\
\text { 計 } \\
\text { 変 } \\
\text { 更 }\end{array}$} \\
\hline & 它 & & & \\
\hline & (統計的手法) & & & \\
\hline & $\frac{1}{2}$ & & & \\
\hline & & & 0 & \\
\hline 綵合的判断 & & & & \\
\hline 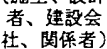 & & YES & 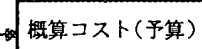 & \\
\hline & & & $\begin{aligned} \text { 万reS } \\
\text { 施工計面人 }\end{aligned}$ & \\
\hline
\end{tabular}

図 1 山留計画概算ロジック（企画計画段階）

手順として、まず、技術面・工程面・コスト面で、その可能性の ある工法の中から、土留壁工法あるいは支保工の適切なものを過去 の経験や統計手法により、推定する。

その場合、(1)工事概要に関する項目（所在地・工期・工事規模な よ゙）、(2)地下工事の概要に関する項目（採用される地下工事の各工 法・地下工事規模なら゙）、(3)工事地盤に関する項目の中から、（土 質条件・柱状図・ $\mathrm{N}$ 値・地下水位など）の各項目が判明すれば、約 $80 \%$ の確率にて工法推定が可能になって来ている。314)

しかし、近隣環境、地域性、施主・設計事務所・建設会社の意 図、工事責任者（所長）の嗜好等により影響される部分も多い。大 規模大深度建築は一般に一品生産としての特殊要因を多分に含むこ ともあり、その都度具体的に可能性のある多くの工法が検討され、 工法比較の中から最終案が決定されて行くケースが多い。

次節以下に最近の大規模大深度工事例約70件の中から標準的なモ デル工事を想定し、採用される可能性のある数種の工法を選定し、 その地下工法内容を概略決定し、全体工期内にて施工可能であるか どうか、概略予算が全体予算の中におさまるかどうか、概算ロジッ クによる計画手法を提案するものである。

工法選定にあたっては「山留壁の工法推定モデルとその推定程度 の比較」 ${ }^{31}$ と「判別分析による山留支保工の推定」 ${ }^{4)}$ がある。

山留壁として「親杭横矢板工法」「シートパイル」「場所打ち壁 （ソイルモルタル壁及 $\mathrm{R} \mathrm{C}$ 連壁）」の中から工法推定をする。

山留支保工については、切梁工法 (井型切梁及び組立集中切梁)、 地盤アンカー工法、逆打工法などが考えられる。特に大深度大規模 工事の場合は、1 $\mathrm{F}$ 床先行工法のように各工法を併用（複合使用） するものも多い。

又、洪積層の良質土で、地下水が低く、ピアを必要としない直接 基礎の大規模工事の場合で、地盤アンカー工法採用が可能な近隣条 件がととのえば、地盤アンカー採用によるオープン掘削が、短工期 で最も経済的に施工出来ることが簡単な分析で理解出来るので、今

回の調查研究からは省略する。

又、 $1 \mathrm{~F}$ 床先行による複合支保工形式による地下掘削工法が採用 されるケースも多くあるが、順打工法と完全逆打工法による地下掘 削法の中間に位置するもので、その都度の要因により、比較出来る ので標準モデル化からは省略する。

その結果、組立集中切梁工法を主たる仮設工法とする地下掘削工 法と、完全逆打工法による地下軀体利用工法とを、工法比較の主た る対象とする。

\section{2 モデル工事の適用範囲}

\section{1) 対象物件}

地下 2 階から地下 4 階程度の地下室を持つ事務所・ホテル・住 宅等の一般建物之する。

2）掘削深度：G L $-10 \mathrm{~m}$ から $20 \mathrm{~m}$ 程度の地下工事とする。

3) 掘削平面積: $45 \mathrm{~m} \times 45 \mathrm{~m}\left(\right.$ 約 $\left.2,000 \mathrm{~m}^{2}\right)$ から $70 \mathrm{~m} \times 70 \mathrm{~m}($ 約 5,000 $\left.\mathrm{m}^{2}\right)$ 程度とする。

4）対象地盤：日本国内の沖積層地盤を対象とし、ピアーなどの支 持層は $\mathrm{G} \mathrm{L}-25 \mathrm{~m}$ 程度とする。止水壁採用時の地下水位は $\mathrm{G} \mathrm{L}$ $3.0 \mathrm{~m}$ 程度とする。

5) 山留壁工法の種類：親杭横矢板工法、シートパイル工法・止水 壁（ソイルモルタル壁及 R C 連壁)'。

6）山留支保工の種類：組立集中切梁工法を主たる仮設工法とする 地下掘削工法々、完全逆打工法による地下軀体利用掘削工法とす る。

\section{3 大深度大規模工事のデータ内容}

1988年から現在工事中の大規模大深度領域（Bゾーン）の集中組 立切梁工法と逆打工法を約 70 件データとして取り上げる。

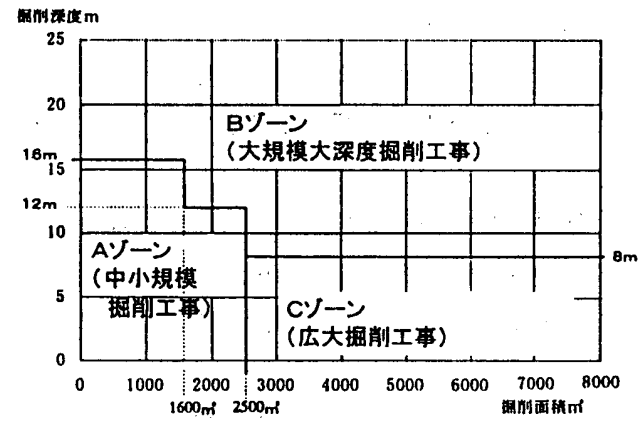

図 2 支保工選定ゾーン

東京地区（44件）を中心に大阪、名古屋、横浜、東北、広島、北 信越等の各地のデータである。このデータの山留支保工件数、工期、 掘削深さ、山留平面積についてのデータを図 $3 、 4 、 5 、 6 に$ 示す。

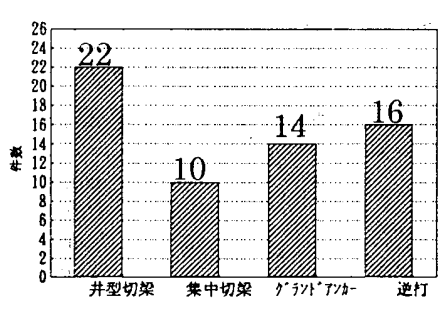

図 3 山留支保工件数

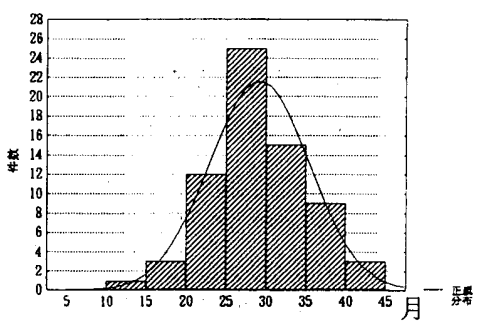

図 4 工 期 


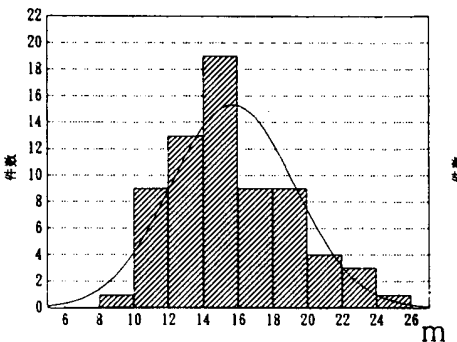

図 5 掘削梁さ

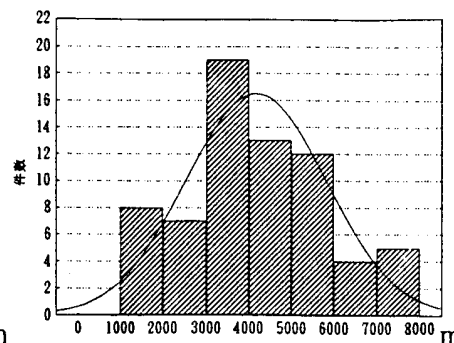

図 6 山留平面積

\section{4 標準モデル建物の工事概要}

(大規模大深度掘削工事) 約 70 件の概要の平均値は表 -1 の如くで ある。

\begin{tabular}{|c|c|c|c|c|c|c|c|c|}
\hline $\begin{array}{c}\text { 掘削深 } \\
\mathrm{m}\end{array}$ & $\begin{array}{c}\text { 山留面 } \\
\mathrm{m}\end{array}$ & 平面 & $\begin{array}{l}\text { 水位 } \\
\text { 差 }\end{array}$ & $\begin{array}{l}\text { 平均 } \\
\mathrm{N} \text { 値 }\end{array}$ & 砂の & 砂の & 粘圭 & 工期 \\
\hline 15.7 & 4168.1 & 2.1 & 11.8 & 10.4 & 0.52 & 17.0 & 3.0 & 29.1 \\
\hline
\end{tabular}

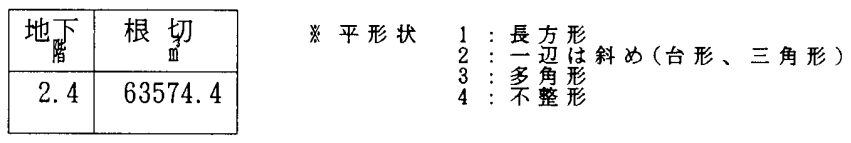

そこで同程度の建物の設計をするための方法論を確立するために、 標準モデル工事を以下の如く仮定する。

(1) 建物の標準スパンは 6,400 として超高層（あるいは高層ビル） で多用されているものとする。平面形としては、9スパン×9 スパンで、「約 $60 \mathrm{~m} \times 60 \mathrm{~m}$ の正方形」とする。（図 7 ）

(2) 地下階数 B 3 階とし、掘削深度は「概算グラフ」図12でモ デル化されている深度とし、G L $14 \mathrm{~m}$ と仮定する。

(3) 地下構造は、超高層部直下柱のみ、すべて地下 S R C 造とす る。低層部は B 10み S R C 造とし、他は R C 造とする。(図 8 )

(4) 土質条件は、データ表 1 の平均值と仮定する。これは東京 地区の下町低地の沖積層の地盤条件に近似している。

(5) 基礎杭は、G L $-25.00 \mathrm{~m}$ を支持層と仮定し、ピアー杭に て支持するものと仮定する。

（6）その他、地上部は $\mathrm{S}$ 造の $20 \mathrm{~F}$ 建しし、これらの結果をふまえ て表 $2 、 3$ に工事概要を示し、図 7 に工事概要図を示す。

(7) 尚、工期の計算には稼動率65\%を用いている。

$$
\text { 表 } 2 \text { 工 事 概 要 }
$$

\begin{tabular}{|c|c|}
\hline 物 件名称 & 標準 \\
\hline 構造名称 & S 造 \\
\hline 用途名称 & 事務所 \\
\hline 期 & 29 ヶ月〜34ヶ月（稼動率 $65 \%$ とする。） \\
\hline 地 面 積 & $4,000.00 \mathrm{~m}^{2}$ \\
\hline 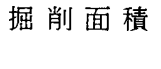 & $\begin{array}{r}3,620.00 \mathrm{~m}^{2} \Gamma 60 \\
\text { 建物 }\end{array}$ \\
\hline
\end{tabular}

延床面積 $51,248.00 \mathrm{~m}^{2}$ 地下階数 3 階地上階数 20 階塔屋階数 2 階

\begin{tabular}{|c|c|c|c|c|}
\hline \multicolumn{5}{|c|}{ 表 3} \\
\hline 階名称 & 軀体構造 & 床 面 積 & 階 高 & 用 \\
\hline B3 & R C 造 & $3,600.00 \mathrm{~m}^{2}$ & $4.00 \mathrm{~m}$ & 機械室 \\
\hline B2 & R C 造 & $3,600.00 \mathrm{~m}^{2}$ & $4.00 \mathrm{~m}$ & 車庫·倉庫 \\
\hline B1 & S R C 造 & $3,600.00 \mathrm{~m}^{2}$ & $4.00 \mathrm{~m}$ & 店舗 \\
\hline 1 & $\mathrm{~S}$ 造 & $3,600.00 \mathrm{~m}^{2}$ & $4.60 \mathrm{~m}$ & ロビー \\
\hline 2 & $\mathrm{~S}$ 造 & $3,600.00 \mathrm{~m}^{2}$ & $3.60 \mathrm{~m}$ & 事務所 \\
\hline 3 & $\mathrm{~S}$ 造 & $3,600.00 \mathrm{~m}^{2}$ & $3.60 \mathrm{~m}$ & 事務所 \\
\hline 4 & $\mathrm{~S}$ 造 & $1,720.00 \mathrm{~m}^{2}$ & $3.60 \mathrm{~m}$ & 事務所 \\
\hline $5 \sim 20$ & $\mathrm{~S}$ 造 & $1,720.00 \mathrm{~m}^{2}$ & $3.60 \mathrm{~m}$ & 事務所 \\
\hline $\mathrm{P} 1 \sim \mathrm{P} 2$ & $\mathrm{~S}$ 造 & $204.80 \mathrm{~m}^{2}$ & $3.60 \mathrm{~m}$ & 機械室・塔屋 \\
\hline
\end{tabular}
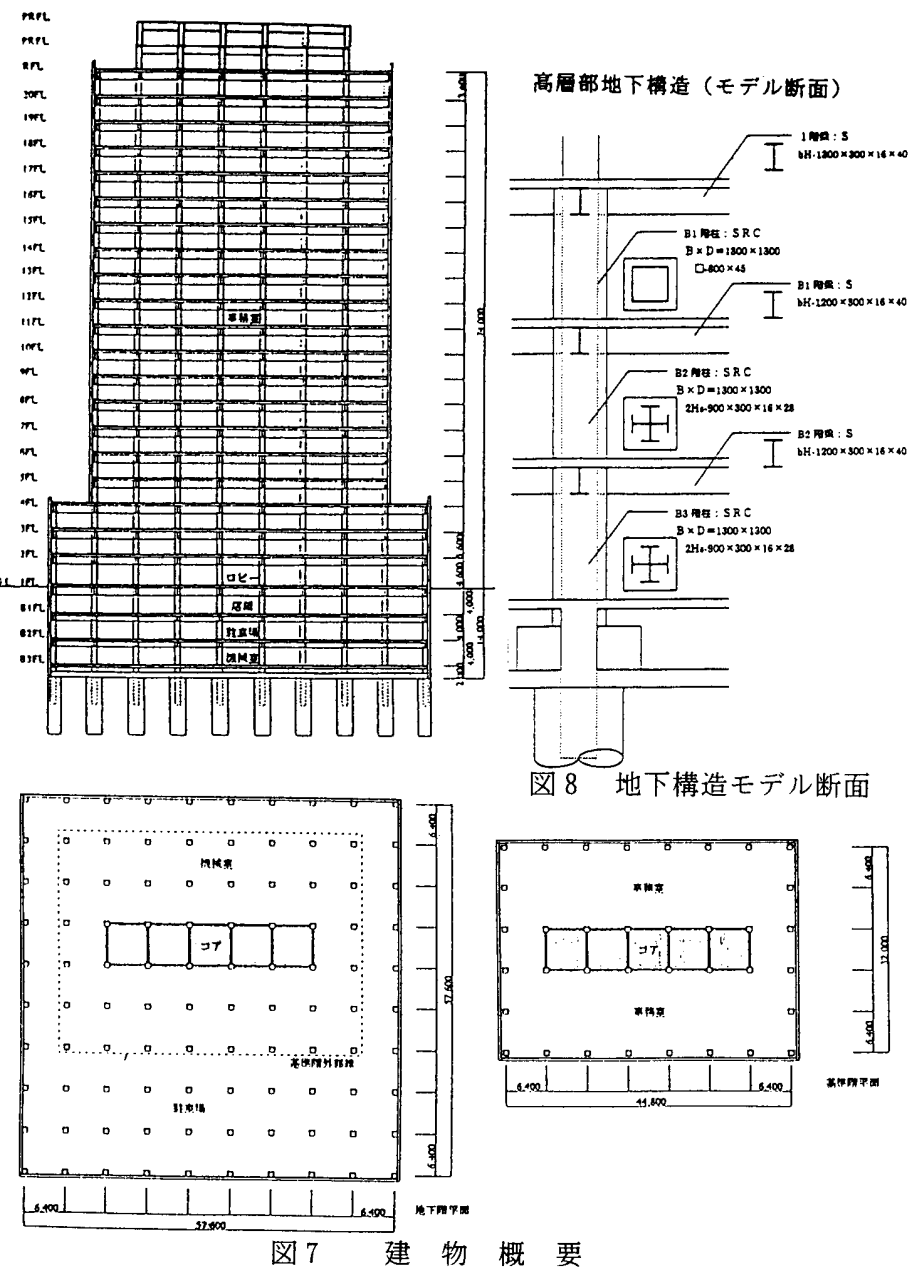

3. 標準モデルエ事の山留工法の推定

「山留壁及支保工の選定に関する統計的分析」の研究論文 ${ }^{314)}$ に 詳述した判別関数式により判別する。

\section{1 土留壁の推定}

判別分析による工法推定モデルの判別式に標準モデルの数値を代 入する。

$$
\begin{aligned}
& \mathrm{x}=1.65 \times 10^{-1} \mathrm{a}+8.09 \times 10^{-5} \mathrm{~b}+4.97 \times 10^{-2} \mathrm{c}+2.59 \\
& \times 10^{-1} \mathrm{~d}-9.54 \times 10^{-2} \mathrm{e}-2.34 \times 10^{-2} \mathrm{f}-1.10 \times 10^{-1} \mathrm{~g} \\
& -5.53 \times 10^{-1} \mathrm{~h}-2.29 \times 10^{-1} \mathrm{i}-1.95 \quad \cdots \cdots \cdots \cdots \cdots \cdots \cdots \cdots .(1) \\
& \mathrm{y}=2.94 \times 10^{-1} \mathrm{a}+1.03 \times 10^{-4} \mathrm{~b}-2.56 \times 10^{-1} \mathrm{c}+5.22 \\
& \times 10^{-2} \mathrm{~d}-6.78 \times 10^{-2} \mathrm{e}+7.21 \times 10^{-2} \mathrm{f}-4.43 \times 10^{-1} \mathrm{~g}
\end{aligned}
$$

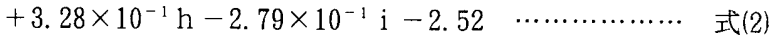

$$
\begin{aligned}
& \text { a : 掘削深度 }(\mathrm{m}) \quad 14 \quad \mathrm{f} \text { : 平均 } \mathrm{N} \text { 值 } \quad 10.4 \\
& \mathrm{~b} \text { : 掘削面積 }\left(\mathrm{m}^{2}\right) 3.620 \quad \mathrm{~g} \text { : 砂割合 } 0.52 \\
& \mathrm{c} \text { : 地下水位差 }(\mathrm{m}) 11 \quad \mathrm{~h} \text { : 粘土割合 } 0.48 \\
& \mathrm{~d}: \text { 粗粒土厚 }(\mathrm{m}) \quad 9 \quad \mathrm{i} \text { : 硬層厚 }(\mathrm{m}) \quad 0 \\
& \mathrm{e} \text { : 細粒土厚 }(\mathrm{m}) \quad 5 \quad \text { 定数： } \quad-1.95
\end{aligned}
$$

以上を代入すると、 $\mathrm{x}=2.811558 \mathrm{y}=-0.03942$

(O)印（座標 $\mathrm{x}=2.811558 、 \mathrm{y}=-0.03942 ）$

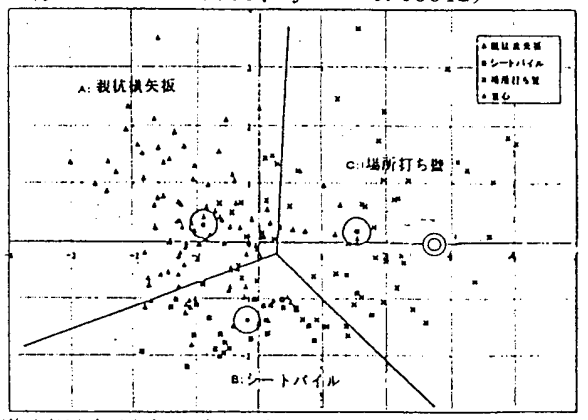

図 9 正準判別空間内の各工事の位㯰（標準モデルビル（○印） 


\section{3， 2 山留支保工の推定}

判別分析による支保工推定モデルの判別式に標準モデルの数値を 代入する。

$\mathrm{x}=-3.95698 \mathrm{~g}-1.06886 \mathrm{e}-0.01516 \mathrm{c}-0.03358 \mathrm{f}-0.00013 \mathrm{~b}$

$+0.157228 \mathrm{a}-0.03424 \mathrm{~d}+0.007622 \mathrm{~h}+3.567565 \cdots$ 式(3)

$y=3.910225 g-0.09166 e+0.098696 c-0.07553 f-0.00028 b$

$+0.126627 \mathrm{a}-0.01514 \mathrm{~d}+0.06897 \mathrm{~h}+0.009001 \cdots \quad$ 式(4)

$\begin{array}{lclc}\mathrm{a}: \text { :掘削深度 } & 14 & \mathrm{e}: \text { : 敷地平面形状 } & 1 \\ \mathrm{~b}: \text { 掘削面積 } & 3,620 & \mathrm{f}: \text { 平均 } \mathrm{N} \text { 値 } & 10.4 \\ \mathrm{c}: \text { 地下水位差 } & 11 & \mathrm{~g}: \text { 砂の割合 } & 0.52 \\ \mathrm{~d}: \text { 砂の } \mathrm{N} \text { 値 } & 17.0 & \mathrm{~h}: \text { 全体工期 } & 29.11 \\ & & \text { 定数 : } & +3.567565\end{array}$

以上を代入すると、 $\mathrm{x}=1.295396 \cdot \mathrm{y}=4.970019$

(2)印 (座標 : $\mathrm{x}=1.295396 \quad \mathrm{y}=4.970019$ )

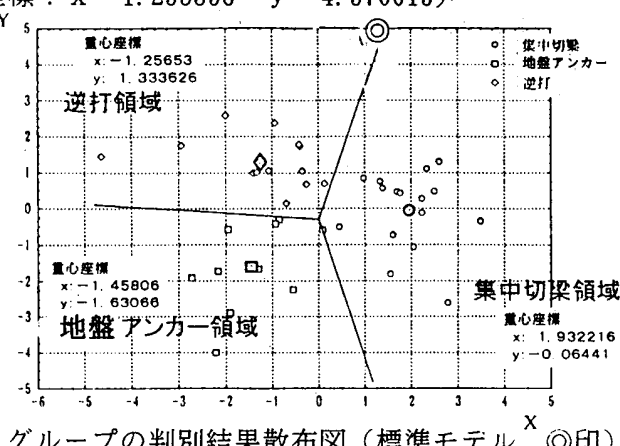

図10 B グループの判別結果散布図（標準モデル ${ }^{\mathrm{X}}$ (0)印)

以上の結果、標準モデル工事としては、山留壁は場所打ち壁を選 定する。山留支保工については、集中切梁領域と逆打領域の境界に 近い所に位置していることがわかるので、両工法の計画内容の仮定 と工程計画・コスト計画及その比較を以下に行う。

\section{4. 順打工法（組立集中切梁）の場合のモデル計画}

地下 3 階の標準モデル工事については、山留壁としては、ソイル モルタル壁( S MW)を採用し、支保工は組立集中切梁 3 段とする。

\section{1 側圧の仮定}

（1）土質の条件は、軟かい粘土地盤を想定し、主働土圧係数 $\mathrm{K}_{\mathrm{A}}=0.5$ と仮定し、主衝土圧 $\mathrm{P}_{\mathrm{a}}=0.5 \gamma \mathrm{H}$ とする。

これは、地下外壁に作用する静止土圧係数之ほぼ同様と考える。

（2）地下水の常水位を $\mathrm{G} \mathrm{L}-3.0 \mathrm{~m}$ と仮定する。

\section{2 山留壁モデルの仮定}

山留計算結果 最大モーメント $\mathrm{M}_{\mathrm{max}} \fallingdotseq 73 \mathrm{t} \cdot \mathrm{m} / \mathrm{m}$ 最大剪断力 $\quad \mathrm{S}_{\text {max }} \leftrightharpoons 49 \mathrm{t} / \mathrm{m}$ となり、

その結果

S MW工法 主材 $\mathrm{H}-500 \times 200 \times 10 \times 16$ @ 450 と仮定する。

\section{3 切梁支保エモデルの仮定}

地下 3 階、軟かい粘土地盤の場合（概算グラフ）より求める。 集中切梁 (ロ) タイプ 図14、図15参照

集中切梁スパン (13,400の場合)

1 段目: 約 $180 \mathrm{t} / 1$ 組集中切梁

$2 \mathrm{H} \quad 300 \times 300 \times 10 \times 15$

2 段目: 約 $560 \mathrm{t} / 1$ 組集中切梁

$3 \mathrm{H} \quad 350 \times 350 \times 12 \times 19$

3 段目: 約 $780 \mathrm{t} / 1$ 組集中切梁 $\quad 3 \mathrm{H} \quad 350 \times 350 \times 12 \times 19$

とモデル支保工を仮定する。
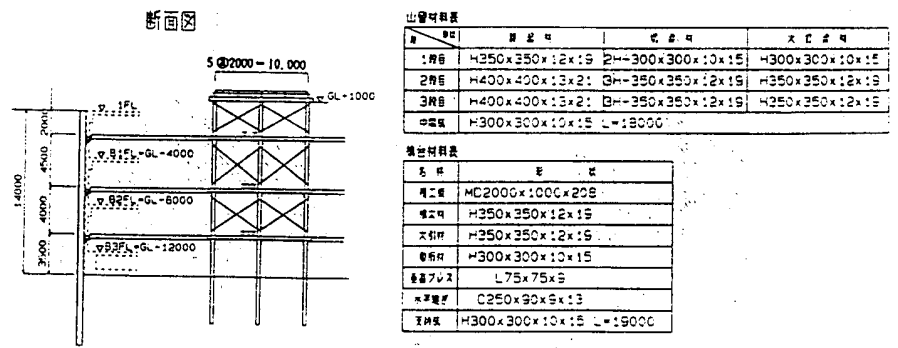

図11 組立集中切梁工法モデル断面図及山留材料リスト

\section{4 山留工事技術計算プログラムによる概算グラフの作製}

「山留計画システム」 ${ }^{5}$ に記載の「山留工事技術計算プログラム」 を利用して作成した「概算グラフ」の内容を以下に記述する。

1）切梁腹起しグラフ作成の条件

組立集中切梁の概算グラフは、以下の条件で作成している。

(1) 根切り深さと躽体レベル、切梁レベル

地下 1 階から地下 4 階まで、標準的な建物の地下を下のよう な深さに仮定する。
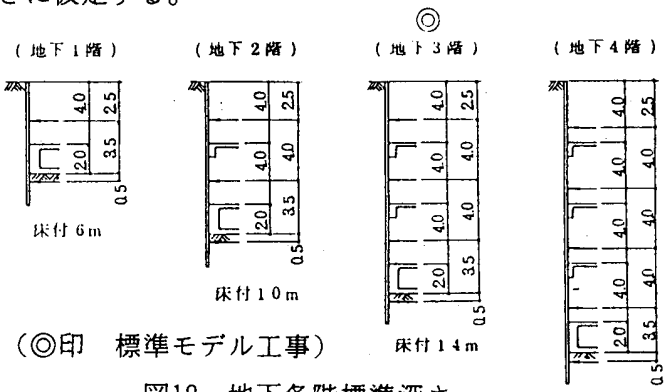

（○印 標準モデル工事）

图12 地下各階標準深さ

(2) 土圧

土圧は各根切り深さ毎に以下の 6 種類の地層を想定し、建築 基礎構造設計規準に示されている土圧を採用した。上載荷重は $1.0 \mathrm{t} / \mathrm{m}^{2}$ の等分布荷重とし、水位は、G L から床付まで、段 階的に変化させる。砂地盤については $\gamma=1.8 \mathrm{t} / \mathrm{m}^{3}$ 、粘土地盤に ついては、 $\gamma=1.7 \mathrm{t} / \mathrm{m}^{3}$ とする。
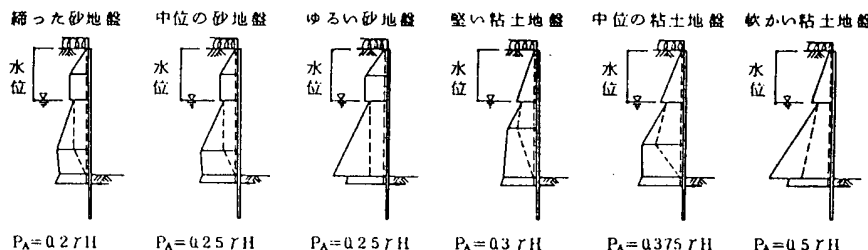

$P_{A}=4375 r H \quad P_{A}=45 r H$

図13各土質条件別の側圧の仮定（@印標準モデル工事）

以下に地下 3 階軟かい粘土地盤(標準モデル工事)の山留設計 概算図表の例を図15に示す。又、今回の標準モデル工事の組立

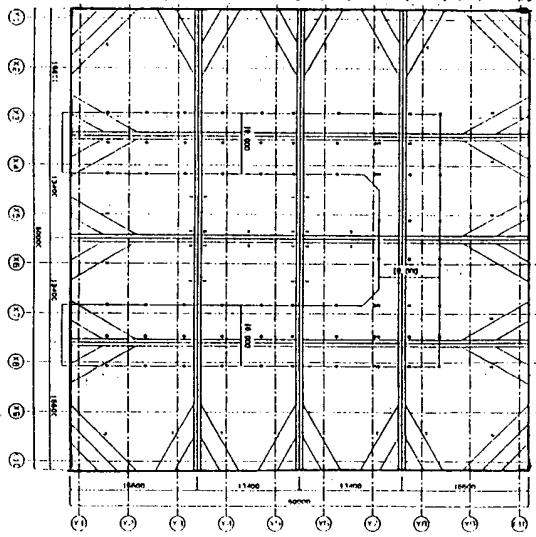
集中切梁の平 面図を図14に 示す。

果中切梁スパン (13,400の場合)

図 14

集中切梁工法 (平面割付図) 




図15
山留設計概算図表（地下 3 階、軟かい粘土地盤の例）

5. 逆打工法 (地下軀体利用工法) の場合のモデル計画

実際の地下空間の設計は、多様化して来ており逆打軀体利用の是 非の判断が困難な場合もあるが、本論文の場合は標準モデルとして 6,400スパン割の地下室とする。

土留壁は順打工法の場合と同様ソイルモルタル壁 ( S MW) とする。 構真柱については、図16の如く、高層直下と低層の中柱及外柱と を区分けて計画している。以下に主たる逆打計画の内容を記す。

\section{1 構真柱エ法のモデル計画}

地下柱に関して大別すると、下記柱プランの通り4タイプに区分

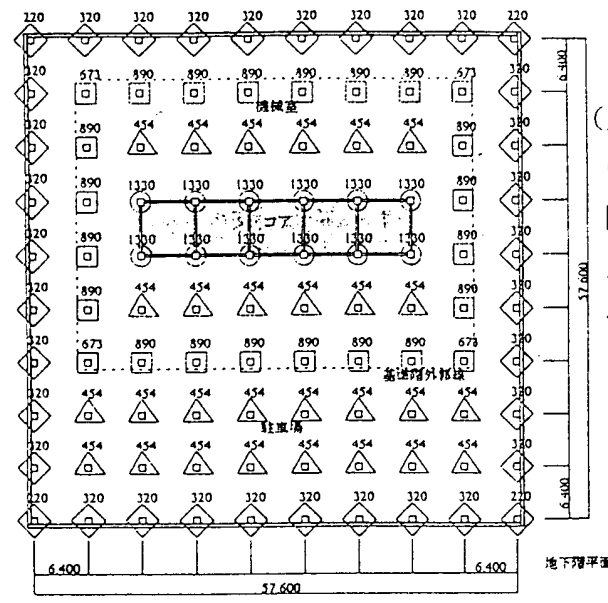

される。

\section{（凡例）}

○印：高度直下の中柱

$\square$ 印：高度直下の外周柱 $\triangle$ 印：低層部中柱 $\diamond$ 印：低層部外周柱

図16 逆打時概算 支持力一覧

○印：高層直下のコア部柱 $(12 \mathrm{P})$

本設鉄骨柱が、B 3 F L まであり、逆打時概算支持力は、約 $1,300 \mathrm{t} /$ 本となる。

〔本設鉄骨柱 =構真柱〕

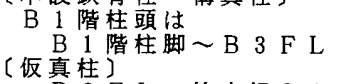

B 3 F L 杭中根入 $2 \mathrm{~m}$

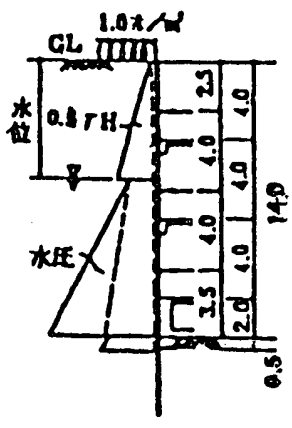

口印：高層直下 の外周柱 (24 P) 本設鉄骨 柱が、B

$3 \mathrm{FL}$ L であり、 逆打時概 算支持力 は、約 900 /本とな

る。
(水位 $G L-m)$

\section{〔本設鉄骨柱=構真柱〕}

B 1 階柱頭 (仮真偕柱脚〜 B $3 \mathrm{~F} \mathrm{~L}$

B 3 F L 杭中根入 $2 \mathrm{~m}$

$\square \quad 800 \times 32$

$2 \mathrm{H} \mathrm{s}-700 \times 300 \times 13 \times 24$ $2 \mathrm{H} \mathrm{s}-700 \times 300 \times 13 \times 24$

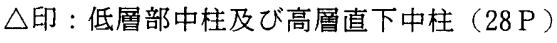

本設鉄骨柱が、B $1 \mathrm{~F} \mathrm{~L}$ まであり、逆打時概算支持力は、約 $450 \mathrm{t} /$ 本となる。

(本設鉄骨桂)

B 1 階柱頭 B 1 F $\mathrm{L}$ 以下

〔仮真柱〕

B $1 \mathrm{~F} \mathrm{~L}$

$\diamond$ 印 : 低層部外周柱

本設鉄骨柱が、B 1 F L まであり、逆打時概算支持力は、約 $320 \mathrm{t} /$ 本となる。

この鉛直荷重を、1 階梁を通して山留壁芯材に負担させる事 とすると、柱裹の山留壁の芯材を 2 本のみ支持層に根入れし ておけばよい。

[本設鉄骨柱〕

$\begin{array}{ll}\text { B } 1 \text { 階柱頭 } & \square \\ \text { B } 1 \text { 階柱脚 } & 200 \times 28\end{array}$

$2 \mathrm{H}-600 \times 200 \times 10 \times 15$

R C $1,100 \times 1,100$

$2 \mathrm{H}-600 \times 200 \times 10 \times 15$

5. 2 床梁計画に関するコメント

構真柱建込精度の問題で、地下階梁は構造上許されれば鉄骨無し のR C とした方が鉄骨取り合いが無くなり施工がしやすい。また鉄 骨が入る梁については、建込誤差を吸収出来る接合方法を充分に検 討しておく必要がある。

又逆打工法において、掘削用開口から長尺鉄骨を投入し、取り付 ける作業は、極力避けたいものである。

梁断面については、梁成を統一し、又水平ハンチ、垂直ハンチを 避けるのも、逆打工法採用時の重要な検討項目である。

更に、逆打工法では掘削に先立って打設される本設軀体の $\mathrm{R} \mathrm{C}$ 床 が架設時に切梁として作用するため、周辺土圧や、プレロードによ る応力のスムーズな流れを妨げないような開口部配置を計画する必 要がある。特に外周部に近い部分の床は注意が必要である。 


\section{6.標準モデル工事の工程計画}

以下に順打工法で施工した場合と、逆打工法で施工した場合の工 程比較を工程表にて表現してみる。図17、18参照。

逆打工法においては、理論的には、1Fスラブ打設後直ちに地上 積層工事に着手する事が出来る。然し乍ら動線管理上、積層工事着 手前に、掘削工事は完了しておきたいので、掘削完了後に地上積層 工事に着手するものとして、工程表は表現してある。この場合でも、
逆打工法を採用する事によって、全体工期は約 $5 \%$ 月短縮する事が 可能である。

一般的には、施主企画側の要望で工期が決まる場合が多い。多く のケースの中から、安全管理、近隣条件、品質管理上の各要素を勘 案し、工程、コスト比較の上、採用工法を決定すべきである。

順打工法と逆打工法の工程比較（地下工事のクリティカルパス） を示すと次の如くである。

\section{図17 順打工法の場合}

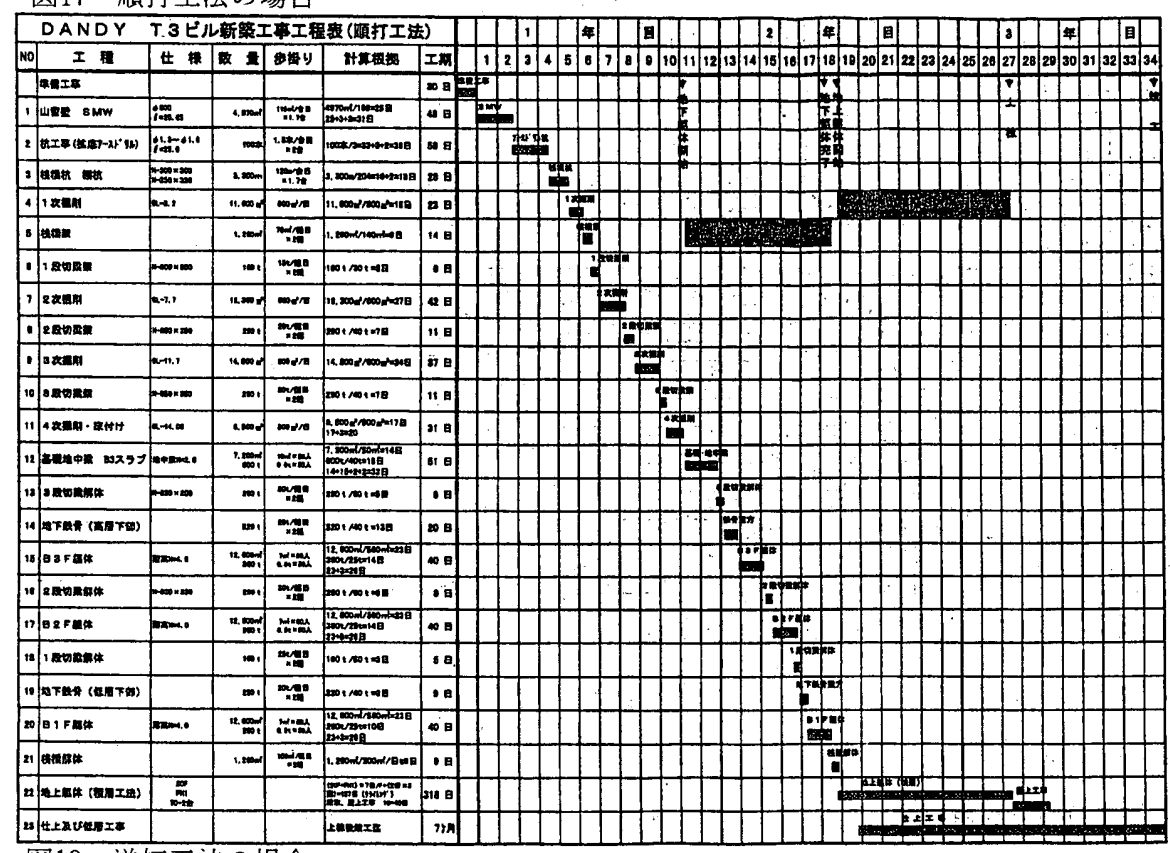

\begin{tabular}{|c|c|c|}
\hline & 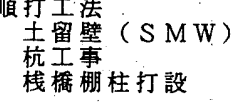 & $\begin{array}{l}4.970 \mathrm{~m}^{2} \\
.100 \text { 本 } \\
3.300 \mathrm{~m}\end{array}$ \\
\hline & $\begin{array}{l}1 \text { 次掘削 } \\
\text { 栈橿設 } \\
1 \text { 段切梁架設 }\end{array}$ & $\begin{array}{r}11,600 \mathrm{~m}^{2} \\
1,260 \mathrm{~m}^{2} \\
160 \mathrm{~T}\end{array}$ \\
\hline & $\begin{array}{l}2 \text { 次掘削 } \\
2 \text { 段切梁架設 }\end{array}$ & 16. $300 \mathrm{~m}^{2}$ \\
\hline & 1 次掘削 & $\begin{array}{l}\text { 4. } 500 \mathrm{~m}^{2} \\
290 \mathrm{~T}\end{array}$ \\
\hline & 4 次掘削床付 & $8,500 \mathrm{~m}^{2}$ \\
\hline
\end{tabular}

(12) 基礎中梁 $\mathrm{B} 3$ スラブ軀体 $\left(3,620 \mathrm{~m}^{2}\right)$ 整格 $7,200 \mathrm{~m}^{2}$ (3) 3 段切梁架設

(14) 地下鉄骨建方（亭首下部）520T $15 \mathrm{~B} 3 \mathrm{~F}$ 軀体 鉄觔 $360 \mathrm{~T}$ 162 段切涩解体 型枠 $12,600 \mathrm{~m}^{2}$

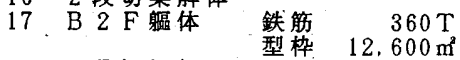
181 段切梁架設 19 地下鉄骨建方（低首下部） $220 \mathrm{~T}$ $20 \mathrm{~B} 1 \mathrm{~F}$ 軁体鉄筀 $260 \mathrm{~T}$ 21 栈橋解体

図18 逆打工法の場合

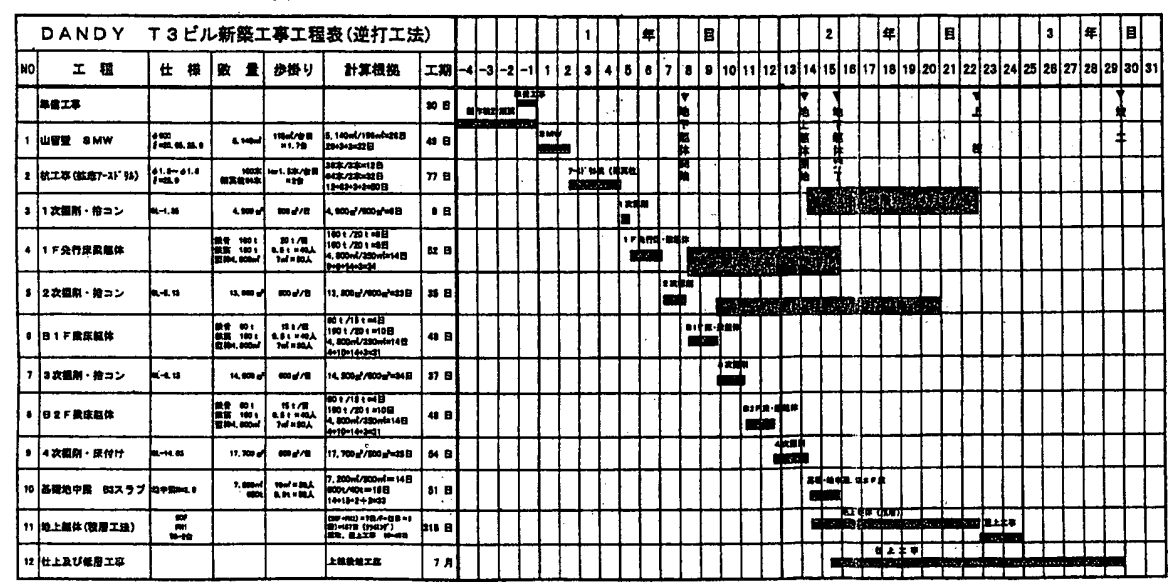

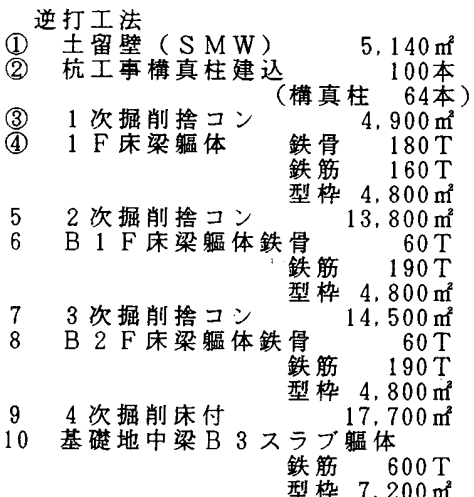

表 4 順打工法の場合の積層工事段取り着手までの月数

工程的な結論としては、順打工法と、逆打工法において、最もク リティカルな工程を検討する。

順打工法の場合は(1)〜迆までの工程は全てクリティカルとなり、 その後地上鉄骨建方及積層工事段取りに着手するまでに13月必要之 なる。一方逆打工法で同様の考元方をした場合、(1)〜(4)の工程がク リティカルとなり、それまでに必要な工期は6ヶ月である。従って 夫々の工法の最早工程で 7 ヶの差が生じる。

ちなみに、この標準モデル工事が、B 2 と浅くなった場合、ある いは、B 4 と深くなった場合、平面的に、XY共 2 スパン広がった 場合、あるいは、XY共 2 スパン狭くなった場合の各々のケースの 積層工事段取り着手までの最早工程を各工法每に比較してリストに すると、表 4 、表 5 の様になる。

\begin{tabular}{|c|c|c|c|}
\hline \multirow[b]{3}{*}{ 地下隦数 } & (-2スパの場合) & (標準モ宁U工事) & (+2スパソの場合) \\
\hline & $47.2 \mathrm{~m} \times 47.2 \mathrm{~m}$ & $60.0 \mathrm{~m} \times 60.0 \mathrm{~m}$ & $72.8 \mathrm{~m} \times 72.8 \mathrm{~m}$ \\
\hline & 約 $2,000 \mathrm{~m}^{2}$ & 約 $3,500 \mathrm{~m}^{2}$ & 約 $5,000 \mathrm{~m}^{2}$ \\
\hline 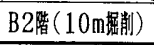 & 9.9 月 & 11.1月 & 12.3月 \\
\hline 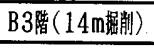 & 11.8月 & 13.0月 & 14.2月 \\
\hline 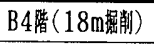 & 14.0月 & 15.2月 & 16.4月 \\
\hline
\end{tabular}

表 5 逆打工法の場合の積層工事段取り着手までの月数

\begin{tabular}{|c|c|c|c|}
\hline \multirow{3}{*}{ 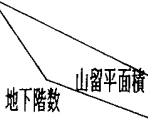 } & (-2スパソの場合) & （標準モデル工事） & (+2スパ場合) \\
\hline & $47.2 \mathrm{~m} \times 47.2 \mathrm{~m}$ & $60.0 \mathrm{~m} \times 60.0 \mathrm{~m}$ & $72.8 \mathrm{~m} \times 72.8 \mathrm{~m}$ \\
\hline & 約 $2,000 \mathrm{~m}^{2}$ & 約 $3,500 \mathrm{~m}^{2}$ & 約 $5,000 \mathrm{~m}^{2}$ \\
\hline B2陵 $(10 \mathrm{~m}$ 掘剈) & 5. 0月 & 5.8月 & 6.0 月 \\
\hline 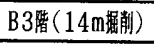 & 5.2月 & 6.0月 & 6.2 月 \\
\hline B4階 $(18 \mathrm{~m}$ 期削) & 5. 4月 & 6.2 月 & 6.4月 \\
\hline
\end{tabular}


順打工法の場合は、地下階数及び地下掘削面積の大小が、そのま まクリティカルパスの中に入ってくるが、逆打工法の場合は、特別 な場合を除いて地下 4 階程度までの地下階数はクリティカルになら ないと言える。又地下掘削面積の大小についても、1 $\mathrm{F}$ 先行床築造 迄の各工事数量のみが、クリティカルパスの中にカウントされ、そ れ以下の軀体数量はカウントされない為、順打工法に較べて工程の 延伸は少ない。

建築工事は与えられた工期の中で、どの工法を採用したらべスト かという検討が必要となるが、特に地下軀体工事は軀体業者の労務 状況に左右される事が多いので、その辺りの状況で採用工法が異な る事も念頭においておく必要がある。又、順打工法の場合は、山留 工事之根切工事の交互作業之なる為、労務山積に山谷が生じ、これ が工程管理上の管理要素となる。

逆打工法を採用した場合は、地下軀体工事の中で、先行床梁軀体 工事のみがクリティカルとなる。その他軀体工事工期は余裕がある ので、平準化された労務で工事を進める事ができ、品質管理上、安 全管理上も好ましい条件を確保できる。

\section{7．標準モデルエ事のコスト計画}

以下に順打工法で施工した場合と逆打工法で施工した場合のコス ト比較をする。

工法選定時のコストスタディについては、下表による比較を行う。

\begin{tabular}{|l|c|c|}
\hline & 順 打 工 法 & 逆 打 工 法 \\
\hline 構真柱関連工事費 & & $\mathrm{C}$ \\
関連架設工事費 & & $\mathrm{D}$ \\
栈橋工事 費 & $\mathrm{A}$ & \\
支保 工 費 & $\mathrm{B}$ & $\mathrm{E}$ \\
先行関連工事費 & & $\mathrm{F}$ \\
逆打関連工事費 & & $\mathrm{C}+\mathrm{D}+\mathrm{E}+\mathrm{F}$ \\
\hline
\end{tabular}

即ち、順打工法における栈橋工事費 $(A)+$ 支保工費 $(B)$ と、逆打 工法における構真柱関連工事費 $(C)+$ 関連仮設工事費 $(D)+$ 先行床 関連工事費 $(E)+$ 逆打関連工事費 $(F)$ とを比較する事により、概略 計画時点でのコスト比較を行う事ができる。

\section{1 順打工法の場合のコスト計算}

栈橋工事費 A（栈橋架払、垂直水平継ぎ架払、栈橋杭打抜、栈橋 杭開口処理等）

$\mathrm{A}=1,260 \mathrm{~m}^{2} \times$ @60,000 @ $70,000 / \mathrm{m}^{2}$ $=75,600,000 \sim 88,200,000$

支保工費 B（腹起切梁架払、棚杭打抜及び開口処理、裏込め等）

$\mathrm{B}=3,620 \mathrm{~m}^{2} \times 3$ 段 $\times @ 15,000 \sim @ 20,000 / \mathrm{m}^{2}$

$=162,900,000 \sim 217,200,000$

$\mathrm{A}+\mathrm{B}=238,500,000 \sim 305,400,000$

順打工法採用の場合、地下階数が増える事により、栈橋工事費は 杭長が長くなり、垂直水平継ぎの段数が増えるので、栈橋架面積当 りの単価は上がる事となる。支保工費についても、背面土圧が大き くなる事により、鋼材メンバーも大きくなり、従って施工面積当り の単価が上がる事となる。

ちなみに、この標準モデル工事が、B 2 と浅くなった場合、ある いは、B 4 と染くなった場合、平面的に、XY共 2 スパン広がった 場合、あるいは、XY共 2 スパン狭くなった場合の各々のケースの 順打工法のコスト比較をすると表 6 の如くになる。
表 6 山留栈橋工事費各ケースのコスト比較

\begin{tabular}{|c|c|c|c|}
\hline \multirow[b]{3}{*}{ 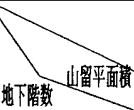 } & (ー2スイ゚ンの場合) & （標準七デル工事） & (+2スパンの場合) \\
\hline & $47.2 \mathrm{~m} \times 47.2 \mathrm{~m}$ & $60.0 \mathrm{~m} \times 60.0 \mathrm{~m}$ & $72.8 \mathrm{~m} \times 72.8 \mathrm{~m}$ \\
\hline & 約 $2,000 \mathrm{~m}^{2}$ & 約 $3,500 \mathrm{~m}^{2}$ & 約 $5,000 \mathrm{~m}^{2}$ \\
\hline 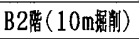 & 0.48 & 0.70 & 1.07 \\
\hline 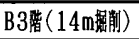 & 0.67 & 1.00 & 1.50 \\
\hline B4㳻 $(18 \mathrm{~m}$ 触制) & 0.96 & 1.43 & 2.14 \\
\hline
\end{tabular}

（標準モデル工事を 1 とする）

次に、根切 $\mathrm{m}^{3}$ 当りの山留栈橋工事費のコスト比較をすると、表 7 の如くに、B 2 階、B 3 階の場合はほぼ等しく、B 4 階の場合は 1 割〜 2 割程度のコストアップになっている。これは、栈橋支柱及 4 段切梁材のサイズアップによるものと考元られる。

表 7 山留栈橋工事費の根切 $\mathrm{m}^{3}$ 当り各ケースの単価比較

\begin{tabular}{|c|c|c|c|}
\hline \multirow{3}{*}{ 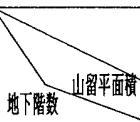 } & (-2スパソの場合) & （標準モت゙l工事） & (+2スパの場合) \\
\hline & $47.2 \mathrm{~m} \times 47.2 \mathrm{~m}$ & $60.0 \mathrm{~m} \times 60.0 \mathrm{~m}$ & $72.8 \mathrm{~m} \times 72.8 \mathrm{~m}$ \\
\hline & 約 $2,000 \mathrm{~m}^{2}$ & 約 $3,500 \mathrm{~m}^{2}$ & 約 $5,000 \mathrm{~m}^{2}$ \\
\hline 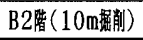 & 1.09 & 0.98 & 1.01 \\
\hline 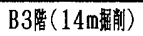 & 1.08 & 1.00 & 1.02 \\
\hline 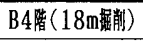 & 1.20 & 1.11 & 1.13 \\
\hline
\end{tabular}

（標準モデル工事を1とする）

\section{2 逆打工法の場合のコスト計算}

構真柱関連工事費 C (構真柱建込費、養生ケレ費、双怢作仮支柱費等) $\mathrm{C}=$ 構真柱建込費他 64 本 $\times 14 \mathrm{~m} \times$ @20,000 @ 25, 000/m $=17,920,000 \sim 22,400,000$

+仮支柱費（高層コア部）

12 本 $\times 2 \mathrm{~m} \times 0.5 \mathrm{t} / \mathrm{m} \times @ 130,000 / \mathrm{t}$ $=1,560,000$

+仮支柱費（高層外周部）

24 本 $\times 2 \mathrm{~m} \times 0.4 \mathrm{t} / \mathrm{m} \times @ 130,000 / \mathrm{t}$ $=2,496,000$

+ 仮支柱費（低層高層中柱） 28 本 $\times 10 \mathrm{~m} \times 0.2 \mathrm{t} / \mathrm{m} \times @ 130,000 / \mathrm{t}$ $=7,280,000$

十外周柱取合 36 本 $\times @ 100,000 /$ 本 $=3,600,000$

十施工床整備費 $3,620 \mathrm{~m}^{2} \times @ 2,000 / \mathrm{m}^{2}$

$=40,096,000 \sim 44,576,000$ $=7,240,000$

関連仮設工事費 D（開口部諸掛、水平運搬施設、換気設備等）

$\mathrm{D}=3,620 \mathrm{~m}^{2} \times 3 \mathrm{~F} \times$ @3,000 @ $4,000 / \mathrm{m}^{2}$ $=32,580,000 \sim 43,440,000$

先行床関連工事費 $\mathrm{E}$ （軀体補強費、養生費等）

$\mathrm{E}=3,620 \mathrm{~m}^{2} \times @ 3,500 \sim @ 4,500 / \mathrm{m}^{2}$

$=12,670,000 \sim 14,480,000$

逆打関連工事費 $\mathrm{F}$ (各工事施工費割増、グラ外、鉄筋ジョ似等)

$\mathrm{F}=46,000 \mathrm{~m}^{2} \times$ @ $200+3,620 \mathrm{~m}^{2} \times 3 \mathrm{~F} \times @ 12,000 \sim @ 15,000 / \mathrm{m}^{2}$ $=139,520,000 \sim 172,100,000$

$\mathrm{C}+\mathrm{D}+\mathrm{E}+\mathrm{F}=224,866,000 \sim 274,596,000$

逆打工法採用の場合、地下階数が増える事により、構真柱関連工 事費は上がるが、先行床関連工事費は変らない。又順打工法の場合 と違って、関連仮設工事費と逆打関連工事費の施工床面積当りの単 価は変らない。

ちなみに、逆打工法の場合も同様に、地下 2 階・地下 4 階、 -2 スパン・+2 スパンの各ケースでのコスト比較を行った結果が表 8 、 表 9 である。

表 8 逆打工事費各ケースのコスト比較

\begin{tabular}{|c|c|c|c|}
\hline \multirow[b]{3}{*}{ 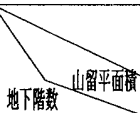 } & (-2スパソの場合) & (標準モデル工事) & (+2スハの場合) \\
\hline & $47.2 \mathrm{~m} \times 47.2 \mathrm{~m}$ & $60.0 \mathrm{~m} \times 60.0 \mathrm{~m}$ & $72.8 \mathrm{~m} \times 72.8 \mathrm{~m}$ \\
\hline & 約 $2,000 \mathrm{~m}^{2}$ & 約 $3,500 \mathrm{~m}^{2}$ & 約 $5,000 \mathrm{~m}^{2}$ \\
\hline 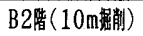 & 0.47 & 0.75 & 1.11 \\
\hline 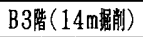 & 0.63 & 1.00 & 1.47 \\
\hline 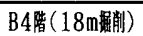 & 0.78 & 1.25 & 1.83 \\
\hline
\end{tabular}

（標準モデル工事を 1 とする） 
表 9 逆打工事費の根切 $\mathrm{m}^{3}$ 当り各ケースの単価比較

\begin{tabular}{|c|c|c|c|}
\hline \multirow{3}{*}{ 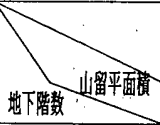 } & (-2スパンの場合) & （標準モでル工事） & (+2スパンの場合) \\
\hline & $47.2 \mathrm{~m} \times 47.2 \mathrm{~m}$ & $60.0 \mathrm{~m} \times 60.0 \mathrm{~m}$ & $72.8 \mathrm{~m} \times 72.8 \mathrm{~m}$ \\
\hline & 約 $2,000 \mathrm{~m}^{2}$ & 約 $3,500 \mathrm{~m}^{2}$ & 約 $5,000 \mathrm{~m}^{2}$ \\
\hline 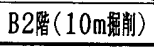 & 1.06 & 1.05 & 1.06 \\
\hline B3陪 (14m期削) & 1.02 & 1.00 & 1.00 \\
\hline 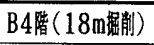 & 0.98 & 0.97 & 0.97 \\
\hline
\end{tabular}

（標準モデル工事を 1 とする）

上表より、逆打工法の場合地下階数が多い方が、コストメリット が大きい事が解かる。

又、掘削 $\mathrm{m}^{3}$ 当りの単価は、順打工法と逆で、地下階数が多い程、 単価が下る傾向にある。

\section{3 両工法の比較と考察}

結果として、標準モデル工事の場合、逆打工法の方が、 $2 \sim 3$ 千万、 割女という結果になった。工期短縮による総合仮設的なメリットを 考えれば、逆打工法の方が更にコストメリットがあると考えられる。 ここで注目しておきたいのが、逆打工法における構真柱関連工事 費が低い事である。仮にベ夕基礎（杭無し）の建物の場合であれば、 逆打工法採用のコストメリットはほとんど発生しない。又仮に、本 体設計の地下柱に鉄骨が入っていなかったとしたら（仮に高層直下 もＢ１ＦＬまでと仮定すると）、そして外周部が、山留壁に鉛直荷 重を負担させる事ができないとしたら、下記の金額が増分となり、 逆打工法採用のコストメリットは極端に低減する結果となる。

ex $(12$ 本 $\times 8 \mathrm{~m} \times 0.5 \mathrm{t} / \mathrm{m}+24$ 本 $\times 8 \mathrm{~m} \times 0.4 \mathrm{t} / \mathrm{m}+36$ 本 $\times 10 \mathrm{~m} \times$ $0.3 \mathrm{t} / \mathrm{m}) \times @ 130,000=30,264,000$

コストスタディをする上での結論として、逆打工法を採用する場 合には、(1)本設杭がある事、(2)仮設構真柱を極力少なくする事の 2 点が重要項目であると言える。

地下階数が増えた場合、順打工法においては、栈橋架面積当りの 単価、支保工架面積当りの単価が上がる事により、結果として地下 施工床面積当りの単価が上がる方向になる。

逆打工法の場合は、構真柱関連工事費は上がるものの、先行床関 連工事費は固定であり、又関連仮設工事費、逆打関婵工事費単価は 変らない為、地下施工床面積当りの単価は、逆に女くなる方向にあ る。従って特殊な場合を除いて、地下階数が多い方が、逆打工法採 用のコストメリットは大きいと言える。

\section{8. 結論}

結論として、標準モデル工事の場合においての順打工法及逆打工 法については次のことが言える。

8. 1 順打工法 (沖積層地盤、B $2 \sim$ B 4 の大規模工事の場合) 地下のある建物の順打工法は、考え方として全ての工程がクリテ ィカルパスで継っている工法である。無理に工期を短縮しようとす れば、安全管理、品質管理を犠牲にしてかなり乱暴な施工計画を要 求される結果となる。長所としては、長年の実績によりコストの把 握が明解であり、工期促成の為の労務・機械の導入も通用する工法 であると言える。
8. 2 逆打工法（沖積層地盤、B $2 \sim$ B 4 の大規模工事の場合）

手間の掛る地下軀体工事を、グリティカルパスからはずす工法で ある。最近では逆打工法の多くの実績から、コストもほぼ明解に把 握できる様になったし、ディテールについても確立された技術であ ると言って良い。工程的には、構真柱建込杭工事及び先行床築造工 事が、順打工法に較べて工期が長くなるものの、それ以降の地下軀 体工事はクリティカルパスから除外される事となる。従って地下階 数が多い程、工程短縮のメリットがあり、コストダウンをはかるこ とが出来る。

8. 3 計画手法については以下の事柄が解明されたと言える。

(1)「標準モデル工事」を想定して地下計画を「モデル化」する ことにより、難解な地下工法の選定及順打工法と逆打工法の工 程・コスト比較を可能にすることができた。

(2) 技術計算による計画内容については、1)地下階数 (B 1 B 4)、 2)地盤条件（砂質地盤 3 分類、粘土地盤 3 分類）別に層別して 「概算グラフ図」を作ることにより、簡明にして早期の検討が 可能である。

(3) 土留壁及支保工の推定については統計的手法より10項目程度の 要因で約 $80 \%$ の正確で立証することが、今回の標準モデル工事 の場合でも証明することが出来た。

\section{謝辞}

本論文をまとめるにあたり、早稲田大学名誉教授 田村恭先生に は、研究全般についてご指導を頂きました。又、早稲田大学理工学 部建築学科の各教授の方々には各分野にわたり色々とご指導、ご鞭 摓を賜り心より御礼申し上げます。

又、大成建設 澤田一郎氏・小林英雄氏・相馬大輔氏・酒田州 亮氏 成和機工侏) 河野寜之助氏・岩永允宏氏 七口セ(侏) 党宣夫 氏にはデー夕収集・解析に多大のご協力を頂きました。

大成建設株式会社 深海謙吉氏はじめ、各支店担当者及各工事関 係者には資料収集、整理にあたりご協力を頂きました。

ここに心より感謝の意を表します。

\section{参考文献}

(1)間瀨惊平：建築工事のおける大規模・大深度掘削の設計と施工 1990.7 基礎工」P $86 \sim$ P 89

(2) 山下丞二、間瀨憤平：山留工事の設計施工 1996.7 初版 P $4 \sim$ P $7 、$ P $34 \sim$ P 36 井上書院

(3)嘉納成男、間瀨憞平、金讯英紀、信田直榕、安畐彩子：山留壁 の工法推定モテルとその推定精度の比較 日本建築学会計画采 論文集 510 号、1998年 8 月号

(4)安畐彩子、嘉納成男、金沢英紀、信田直裕、間濑嵉平：地下工 事における実續資料の統計的分析（その3） 判別分析に上る山 留支保工の推定 1996年 日本建築学会関東支部研究報告集 P $345 \sim$ P 348

(5)間瀨惊平：「山留め計画システム」土質・基碮エ学へのコン ピュータ利用入門（共著）Ｐ 69〜 土質工学会編（1979年 2 月 発行)

(6) 山留設計施工指針：1988.1第 2 版 P 23〜 P 27 日本建築学会 (7) 榎亚昭、内山和夫、笠井劳夫、毛見虎雄、間瀬嵉平他：「鉄筋 コンクリート地下構造物の解体工法（建築業協会編）P 27〜P 114 鹿島出版会 1987年 1 月初版

(1998年. 6 月 9 日原稿受理，1998.年 8 月21日採用決定) 